\title{
Highlights in Cellular and Molecular Mechanisms of Allergic Diseases
}

\author{
XXVth Congress of the European Academy of Allergology and Clinical Immunology in \\ Vienna
}

\author{
T. Basinski ${ }^{a, d}$ C. Ozdemir ${ }^{b} \quad$ C. Sackesen ${ }^{a, c} \quad$ P.-Y. Mantel ${ }^{a} \quad$ I. Barlan ${ }^{b} \quad$ M. Akdis ${ }^{a}$ \\ M. Jutel ${ }^{d}$ C.A. Akdis ${ }^{a}$ \\ ${ }^{a}$ Swiss Institute of Allergy and Asthma Research, Davos, Switzerland; ${ }^{b}$ Division of Pediatric Allergy and \\ Immunology, Marmara University, Istanbul, and 'Pediatric Allergy and Asthma Unit, Hacettepe University School \\ of Medicine, Ankara, Turkey; ${ }^{\mathrm{d}}$ Department of Internal Medicine and Allergology, Wroclaw Medical University, \\ Wroclaw, Poland
}

\section{Key Words}

Immune regulation $\cdot$ Inflammation $\cdot$ T cells $\cdot B$ cells .

Dendritic cells $\cdot T$ regulatory $\cdot \lg E \cdot$ Transcription factors

\begin{abstract}
This year, the annual congress of the European Academy of Allergology and Clinical Immunology was held on 10-14 June in Vienna. More than 6,000 delegates, practicing bench or bedside work or both, gathered from over 50 countries throughout the world. Health professionals, basic scientists and fellows in training could choose between a variety of activities in plenary, main, educational and workshop sessions, highlights of the past year, pros and cons, and oral abstract and poster sessions, and met with experts. A total of 1,713 abstracts, 31 symposia, and 54 workshops were presented, ranging from basic science to clinical trials and modern treatment of allergic diseases. Here, we summarize the highlights of cellular and molecular mechanisms of allergic disease.

Copyright $\odot 2007$ S. Karger AG, Basel
\end{abstract}

\section{T Cell, B Cell, and Dendritic Cell Interactions in Innate and Adaptive Immune Responses}

T Cells

A large proportion of the annual congress of the European Academy of Allergology and Clinical Immunology (held on June 10-14, 2006, in Vienna) was devoted to understanding the paradigm of the suppressive functions of regulatory $\mathrm{T}\left(\mathrm{T}_{\text {reg }}\right)$ cells and the role of a novel subpopulation of T cells, Th17 cells. $\mathrm{T}_{\text {reg }}$ cells appear to keep the immune response under control, in many aspects, because dysfunction of these cells has been demonstrated in different autoimmune diseases, tumor growth, transplant rejection, chronic infections, allergy and asthma [1-4]. Therefore, targeting $\mathrm{T}_{\text {reg }}$ cells may have a great potential in the treatment of these diseases. In this context, it was shown that rapamycin selectively expands $\mathrm{CD} 4+\mathrm{CD} 25+\mathrm{FoxP} 3+\mathrm{T}$ cells in vitro [5]. These cells suppress proliferation of syngeneic $\mathrm{T}$ cells in vitro and prevent allograft rejection in vivo. A recently published study by Coenen et al. [6] also showed that rapamycin may increase the suppressive potential of human CD4+CD25+ $\mathrm{T}$ cells in autoimmune responses in vitro. An original

\section{KARGER \\ Fax +41613061234 \\ E-Mail karger@karger.ch}

www.karger.com
Correspondence to: Dr. Cezmi Akdis

Swiss Institute of Allergy and Asthma Research, SIAF

Obere Strasse 22

CH-7270 Davos (Switzerland)

Tel. +41 814100848, Fax +41 81410 0840, E-Mail akdisac@siaf.unizh.ch 
lecture was delivered by Akbar, who stressed the need to better understand the influence of $\mathrm{T}$ cell homeostasis and senescence in young and elderly humans. It is especially important in the light of the fact that the human average lifespan in the developed countries has significantly increased over the last hundred years [7]. Using a sophisticated method with deuterium-labeled glucose, the lifespan of different $\mathrm{T}$ cell subsets was estimated, namely 198 days for naive CD4+CD25-RA+ T cells; 24 days for memory CD4+CD25+RO+ $\mathrm{T}$ cells and 8 days for $\mathrm{T}_{\text {reg. }}$.

$\mathrm{M}$. Akdis elaborated on the regulation of the $\mathrm{B}$ cell isotype switch by IL-10-producing as well as CD4+CD25+ $\mathrm{T}_{\text {reg }}$ cell subsets. Antibody isotype regulation by Th1 and Th2 cells has been reported previously, whereas antibody regulation in $\mathrm{T}_{\text {reg }}$ cell-B cell interaction has not been known yet. She presented interesting results showing that IL-10-producing $\mathrm{T}_{\text {reg }}$ cells induced $\operatorname{IgG}_{4}$ and IgA production and additionally IL-10, TGF- $\beta$, Trl cells, and $\mathrm{CD} 4+\mathrm{CD} 25+\mathrm{T}_{\text {reg }}$ cells inhibit IgE synthesis by B cells.

The role of $\mathrm{T}_{\text {reg }}$ cells in allergy and health was further discussed by Kapsenberg [8], who reviewed the existing data on the role of dendritic cells (DC) in the induction of peripheral tolerance. He suggested that different probiotics may have different immunomodulatory properties and promote mucosal tolerance, which is in part mediated by $\mathrm{T}_{\text {reg }}$ cells. It is probable that probiotics act via pattern recognition receptors on DC to induce DC subsets, which promote the generation of $\mathrm{T}_{\text {reg }}$ cells. The protective and therapeutic effect of microbial products in atopy was also the subject of a presentation by Di Felice et al. $[9,10]$. They used a mouse model of allergen sensitization to the major pollen allergen of Parietaria judaica (rPar j 1) to study the immunomodulatory activity of a mixture of different probiotics. The prophylactic treatment with probiotics induced a significant reduction in serum total and specific IgE as well as specific $\operatorname{IgG}_{1}$. It was accompanied by a significant increase in the production of IFN- $\gamma$ and a significant reduction in splenic IL- 4 secretion. They also showed an increase in IL-10 and IFN- $\gamma$ in bronchoalveolar lavage (BAL) fluid analysis. Their results point to an immunomodulatory role of probiotics, especially through IL-10 and IFN- $\gamma$, and thus a role in IgE suppression.

Another highlight of the meeting was a newly described subpopulation of Th cells, the Th17 cells, that are characterized by the secretion of IL-17 and to lesser extend IL- 8 and GM-CSF $[11,12]$. Th17 cells are distinct from the Th1, Th2 or $\mathrm{T}_{\text {reg }}$ and have potent proinflammatory properties. IL-17 promotes granulopoiesis and neutrophil accumulation at the site of inflammation, playing a crucial role in the protection against bacterial infections. In mice, in the presence of the proinflammatory cytokine IL-6, TGF- $\beta$ induces differentiation of Th17 cells. IL-23, both an IL-2 receptor $\gamma$ chain and IL-12 cytokine family member, has been shown to be involved in the survival and expansion of Th17 cells $[13,14]$. Transcription factors responsible for Th17 lineage commitment have not been identified until present. Sallusto in her talk reviewed current knowledge on Th17 cells and emphasized their key role, together with Th1, Th2 and $\mathrm{T}_{\text {reg }}$ cells, in specific immune response. She also provided new insights into the role of zymosan, an insoluble cell wall polysaccharide of the yeast Saccharomyces cerevisiae in Th17 cells lineage commitment. She showed that zymosan, that acts through Toll-like receptor (TLR)-2, selectively induces IL-23 secretion, but not IL-12 by DCs. In an attempt to identify a specific marker for Th17 cells, Sallusto et al. demonstrated the chemokine receptor CCR6. However, this chemokine receptor is not only specific for Th17, it is also expressed on memory T cells and T cells secreting IFN- $\gamma$ and IL-10. Nonetheless, measurement of CCR6 expression allows to exclude Th2 cells. Furthermore, her group identified human Th17 clones against Candida, suggesting a role for Th17 in the immune response against fungi. The theme of Th17 cells and innate immune response was continued by de Jong. She presented data on priming human monocyte-derived DCs in vitro on their ability to promote the development of Th17 cells. Among different TLR agonists, her group identified peptidoglycan as a key bacterial constituent in terms of induction of IL-17 secretion by memory T cells and promotion of Th17 cell development. Peptidoglycan acts via TLR2 and the nucleotide-binding oligomerization domain modulating TLR2 signaling, which leads to the production of high levels of IL- 23 by primed DCs. Interestingly, several viruses which they tested were not able to prime DCs to induce Th17 cell differentiation [15].

Allergic inflammation is not only localized to allergen-affected tissues, it might also influence the entire body. Bossios et al. [16] generated data in support of the concept that the body distribution of newly produced $\mathrm{T}$ cells upon allergen exposure is changed. They used intraperitoneally given bromodeoxyuridine in ovalbuminsensitized $\mathrm{BALB} / \mathrm{c}$ mice to label newly produced cells upon ovalbumin challenge. CD3+ and bromodeoxyuridine-positive cells from various organs and BAL fluid were determined by flow cytometry. Significant increases in the proportion of newly produced CD3+ cells were found in the bone marrow, lung and BAL fluid. Interest- 
ingly, there was no change in the distribution of cell populations in the lymph nodes, blood and spleen. The above results indicate that airway inflammation alters the distribution of CD3+ cells in the body, supporting the hypothesis that it is a systemic disease.

\section{Dendritic Cells}

Depending on the microbial information they encounter in peripheral tissues, DCs promote the development of different specific $\mathrm{T}$ cell responses. It is also known that a tryptophan-degrading enzyme, indoleamine 2,3dioxygenase (IDO), can be a potent inducer of immunosuppression and tolerance in vivo and in vitro. It is expressed by some antigen-presenting cells upon inflammatory stimuli, and it has been shown that allergic asthma can be abrogated by IDO-expressing epithelial cells in the lung. TLR9 ligand-induced pulmonary IDO activity by epithelial cells of the lung inhibits Th2-driven experimental asthma [17]. von Bubnoff et al. showed that tryptophan deprivation affects the T cell-stimulatory capacity of DCs. As determined by flow cytometry, human monocyte-derived DCs generated in the absence of tryptophan demonstrated altered expression of surface antigens related to antigen presentation and costimulatory activities and were weak inducers of $\mathrm{T}$ cell stimulation. In conclusion, IDO may in part regulate tolerance induction by its modulatory effect on DCs [18].

The innate immune system serves as a sensor in the identification of the invading pathogens and modulates the type of adaptive immune response. IL-12 produced by DCs leads to the differentiation of naive CD4+ T cells into Th1 cells, mounting an effective immune response against pathogens, but may also lead to autoimmune diseases and chronic forms of allergic inflammation. The cells providing this initial IL-12 remain to be elucidated. Schäkel in his talk described a subset of DCs, which is the principal and primary source of IL-12p70, when blood leukocytes are either stimulated with TLR4-ligand lipopolysaccharide or CD40-ligand. These so-called slanDCs are characterized by the 6-sulfo LacNAc, an O-linked carbohydrate modification of P-selectin glycoprotein ligand-1, and by the expression of the following markers: CD162, CD1c-, CD11c+, CD16+, CD14-, C5aR+ and CD45RA+. They account for the majority of DCs in human blood (0.6-2\% of PBMCs). Interestingly, the IL-12 response and maturation of slanDCs are completely blocked in coculture with erythrocytes. This inhibition of maturation depends on the expression of CD47 on erythrocytes and of its ligand signal-regulatory protein$\alpha$ on DCs. Although slanDCs are potent cells secreting
IL-12 and TNF- $\alpha$, inhibition of their maturation by erythrocytes might prevent overreaction of slanDCs in the circulation [19].

Matricardi in his presentation pointed out the discrepancy of promising results of mycobacteria in mouse models and lack of such data in human studies. He concluded that it may still be worthwhile to investigate whether $\mathrm{T}_{\text {reg }}$ cells are induced in response to different mycobacterial strains, as demonstrated in humans [20, 21]. Fuchs presented interesting results on the preventive effect of the Mycoplasma fermentans-derived lipopeptide MALP-2 derivate bisacyloxypropylcystein (BPPcysPEG) on asthma in a mouse model. BPPcysPEG is a synthetic TLR2/ TLR6 agonist and is thought to mimic bacterial infection. Fuchs et al. [22] studied five treatment groups; BPPcysPEG, IFN- $\gamma$, BPPcysPEG/IFN- $\gamma$ and dexamethasone in mice. They found that eosinophil numbers were significantly diminished in BAL fluid after treatment with either dexamethasone or BPPcysPEG/IFN- $\gamma$ compared to vehicle control. They did not observe any induction of neutrophils. Response to methacholine was also improved. Their findings suggested that treatment with BBPcysPEG and IFN- $\gamma$ could shield from asthma symptoms, and the combination might be used as an adjuvant in allergen-specific immunotherapy and for allergy prevention [22].

\section{B Cells and IgE Regulation}

The theme of the innate immune system was continued by Sackesen. She presented captivating data on the effect of suppressive oligonucleotides, which are repetitive TTAGGG sequences as expressed in mammalian telomeric DNA, on human B cells. Her investigation revealed the effects of suppressive oligonucleotides on human B cell activation and antibody production. Purified B cells were stimulated with specific ligands for TLR2TLR 9 in the presence or absence of suppressive oligonucleotides. B cell differentiation, proliferation and antibody production were determined. Circulating B cells proliferated and turned into antibody-secreting cells in response to TLR3, TLR7 and TLR9 ligands. All three TLR ligands similarly induced a program of B cell activation leading to blast formation with increased expression of CD27, CD38, CD86, B cell maturation antigen, CD19 and CD20. Determination of the frequency of antibody-producing cells revealed that only a fraction of activated $\mathrm{B}$ cells turned into IgA. Some of the cells became $\operatorname{IgG}_{1^{-}}$and $\mathrm{IgG}_{4}$-producing plasma cells, whereas a high percentage remained as memory B cells. Suppressive oligonucleotides significantly inhibited all of the mentioned fea- 
tures of B cells demonstrating a natural mechanism for the control of B cell memory. Her group concluded that host-derived telomere oligonucleotides can downregulate B cell maturation and antibody responses [23].

The theme of IgE regulation was the subject of several other presentations. Marth presented evidence for a stable repertoire of allergen-specific IgE in allergic individuals [24]. Her group analyzed variable regions of major birch pollen allergen (Bet vl)-specific IgE in patients with seasonal allergy. They found more limited numbers of sequences coding for variable regions for Bet v1-specific IgE. Experiments repeated after three birch pollen seasons showed almost no change in the Bet v1-specific IgEvariable region repertoire, indicating that the repertoire of allergen-specific IgE is derived from a pre-established pool of IgE-producing cells.

Vercelli gave a talk on the results of the ALEX study. One of the aims of this study was to analyze allergen-specific immune responses in 9-year-old children that had grown up in city or countryside environments. In support of the hygiene hypothesis, the study indicated that serum levels of allergen-specific $\operatorname{IgG}_{1}, \operatorname{IgG}_{4}$ and $\mathrm{IgE}$ were reduced in children living on farms. At the same time, the levels of allergen-specific $I_{g} G_{2}$ and $I_{g G}$ were unchanged. It was emphasized that different allergens may generate specific humoral immune responses in terms of types of antibody classes due to a sequential process of immunoglobulin isotype switching. Because the $\mathrm{IgG}_{1}$ gene is upstream of the immunoglobulin locus, its expression is a prerequisite for downstream locus switching. She also presented data indicating the absence of $\operatorname{IgG}_{1}$ was associated with low IgE and $\mathrm{IgG}_{4}$ for many types of allergen. In line with Vercelli's talk was a lecture given by Launer. He summarized different aspects of the role of microbial components on the modulation of immune responses [25-27]. Low doses of lipopolysaccharide cause eosinophilia, high secretion of IL-5 and IL-13 and high IgE production. On the other hand, high doses of lipopolysaccharide are responsible for increases in IFN- $\gamma$ and $\operatorname{IgG}_{2 \mathrm{a}}$. TLR ligands for TLR 2 and TLR8 can activate $\mathrm{T}_{\text {reg }}$ cells, but interestingly TLR signaling reverses the suppressive effect of $\mathrm{T}_{\text {reg }}$ cells. High-dose endotoxin, the best-known farm exposure product, induces high expression of suppressor of cytokine signaling-1, which has inhibitory function on TLR signaling, leading to less IFN- $\gamma$ production.

It is well known that a subset of food-allergic patients responds clinically not only with symptoms in the gastrointestinal tract, but also with asthmatic reactions [28]. Ozdemir et al. [29] studied the role of intestinal mesen- teric CD4+ T cells on food-induced immediate-type hypersensitivity in the development of asthma. They described a food-induced intestinal immediate-type hypersensitivity model in ovalbumin-sensitized BALB/c mice after intragastric challenges. In their model, they demonstrated eosinophilic infiltration in small intestinal specimens, as well as goblet cell hyperplasia and shortened villus height/crypt depth ratios, representative findings of food allergy. After various aerosol ovalbumin challenges, they demonstrated airway hyperreactivity and eosinophilic airway inflammation in CD4+ cell-transferred naive mice.

\section{Effector Cells and Mechanisms of Allergic Inflammation}

Mast cells are major effector cells in IgE-mediated allergic diseases. Essential signals for mast cell activation occur after the cross-linking of the IgE receptor, FceRI, which then leads to the secretion of preformed mediators and de novo synthesis of proinflammatory leukotrienes and cytokines. Gutermuth presented a novel signaling pathway in mast cells. He showed that mice deficient in Bcl-10 or Malt1 are severely impaired in terms of IgE-dependent late-phase anaphylactic reactions. Even though proximal signaling and degranulation are normal in these animals, mast cells cannot produce TNF- $\alpha$ and IL6 upon FceRI ligation, due to impaired activation of NF$\kappa \mathrm{B}[30]$. Another regulatory pathway of the mast cells was discussed by Maurer. He reminded that despite their unwanted IgE-associated effects, mast cells contribute to host defense against invading bacteria [31]. His group used $\mathrm{Kit}^{\mathrm{W}} / \mathrm{Kit}^{\mathrm{W}-\mathrm{v}}$ mice deficient in mast cells. Mast celldeficient mice infected to develop septic peritonitis succumbed to sepsis, indicating a critical role of mast cells as a source of TNF- $\alpha$, which stimulates neutrophils in an early immune response. When an infected mouse mast cell population was increased via administration of stem cell factor, these mice were less susceptible to septic peritonitis. Another example was the process of effective wound healing, which is positively influenced by mast cells. The processes were not related to IgE and FceIIR, because blocking of IgE does not prevent the observed effects.

Other important cells involved in allergic inflammation are basophils. The activation of these cells via crosslinking of IgE and a role of histamine receptor 2 (HR2) in this process has been investigated by Mete et al. [32]. Purified basophils from whole blood, which are known 
to express HR2, were stimulated by the HR2 agonist dimaprit. Stimulation with dimaprit significantly suppressed basophil activation after surface IgE cross-linking, which was determined by CD203c expression on the cells. Since it is known that HR2 induces cAMP, they used forskolin and were able to suppress activation of basophils upon anti-IgE cross-linking. Release of sulfidoleukotrienes by activated basophils was also diminished by both dimaprit and forskolin. HR2 expressed on human basophils represents a novel target for the treatment of allergic inflammation, because of its ability to rapidly suppress basophil degranulation and activation upon surface IgE cross-linking.

The role of the complement cascade in allergic disease has been confusing and controversial [33,34]. Wang presented interesting results on the use of anti-mouse and anti-human $\mathrm{C} 5$ antibodies (mAbs) to block intrapulmonary activation of C5 via nebulization [35]. Ovalbumin-sensitized and -challenged mice developed airway inflammation with significantly elevated intrapulmonary $\mathrm{C} 5$ activity and transepithelial infiltration of inflammatory cells. Nebulization of anti-C5 mAb inhibited $\mathrm{C} 5$ in the lungs in a dose-dependent manner without affecting serum C5 activity. Repeated chronic aerosol administrations of anti-mouse $\mathrm{C} 5 \mathrm{mAb}$ did not cause detectable changes in the airways of normal BALB/ $c$ mice. Yi Wang's group demonstrated that a single nebulization of either anti-mouse C5 mAb or dexamethasone significantly blocked methacholine-induced airway hyperresponsiveness in mice with established airway inflammation. The nebulization of a combined dose of corticosteroid and anti-C5 $\mathrm{mAb}$ had better efficacy than monotherapy.

Neutrophins, including nerve growth factor, brainderived neutrophic factor, neutrophin-3 and neutrophin4 , seem to be another important regulator of allergic asthma. Neutrophins have been shown to play an important role in the development of allergic asthma by increasing airway inflammation and hyperreactivity [36]. In order to identify the potential target cells of neutrophins, Nassenstein et al. [37] analyzed the expression of high-affinity neutrophin receptors (Trk), namely TrkA, $\operatorname{TrkB}$, and TrkC, in a murine model of asthma. They observed that all Trk receptors were constitutively expressed in large nerve bundles as well as in small nerve fibers surrounding the airways. Moreover, TrkA and TrkC were expressed in airway smooth muscle cells. After allergen provocation, there was a marked increase in infiltrating Trk + cells, notably TrkB + and TrkC+ cells. Further investigations revealed that Trk+ cells belong to a heteroge- neous group of CD45+ leukocytes. Infiltrating CD19+ B cells, CD4+ T cells, and DEC205+ (membrane glycoprotein, DCs and epithelial cells, $205 \mathrm{kDa}), \mathrm{CD} 11 \mathrm{c}+$ and MHC class II antigen-presenting cells expressed those receptors. They suggested that allergen contact may lead to an enhanced infiltration with Trk+ cells and/or to an upregulation of Trk receptor expression. Therefore, they hypothesized that neurotrophins might affect allergic airway inflammation by influencing different immune cell populations.

The correlation between allergy development and natural killer (NK) cell phenotypes in childhood was presented by Sundstrom [38]. Mononuclear cells collected from cord and peripheral blood of 2- and 5-year-old allergic and non-allergic children were compared by flow cytometry. NK cells, isolated from cord blood of children that later developed allergy, expressed more NKp30 receptors and less of the activating NKG2C/CD94 receptor complex compared to non-allergic children. Cord blood from children that later developed allergy contained also smaller populations of CD56bright NK cells. At 2 years of age, NK cells from allergic children showed a reduced capacity to produce IFN- $\gamma$ in response to stimulation with IL-2 and IL-12. Sundstrom's group stated that differences in the NK cell phenotype in the cord blood may suggest a predisposition towards allergy.

The novel pathogenic link between T cells and pruritus in atopic skin inflammation was the subject of a talk by Sonkoly [39]. Using real-time RT-PCR, Sonkoly demonstrated that IL-31 was significantly overexpressed in 'pruritic' atopic compared to 'non-pruritic' psoriatic skin lesions. Moreover, in vivo, staphylococcal superantigen, enterotoxin B, was shown to rapidly induce IL-31 expression in atopic individuals. Furthermore, activated leukocytes expressed significantly higher IL-31 levels in atopic dermatitis patients compared to control subjects. Their findings provide a new link between staphylococcal colonization, subsequent $\mathrm{T}$ cell recruitment/activation and pruritus in atopic dermatitis patients, and emphasize that IL-31 may represent a novel target for antipruritic drug development.

It has recently been demonstrated that epithelial activation and apoptosis play an important role in the pathogenesis of eczematous dermatitis and asthma [40]. Tomasz Basinski et al. [41] presented new data on the mechanisms of activation-induced cell death of human sinus epithelial cells (HSEC) in the pathogenesis of chronic rhinosinusitis. They showed that IFN- $\gamma$ is a major factor which induces the activation of HSECs by upregulation of MHC class II molecules and sensitizes HSECs to the apop- 
tosis induction by TNF-related apoptosis-inducing ligand (TRAIL) and Fas ligand (FasL). Interestingly, TRAIL and FasL alone did not induce apoptosis of HSEC. T cells infiltrating sinus epithelium from chronic rhinosinusitis individuals were found to express more TRAIL compared to healthy individuals. Coculture experiments of HSEC with activated sinus-infiltrating $\mathrm{T}$ cells followed by blocking of IFN- $\gamma$ demonstrated that IFN- $\gamma$ is an effector factor, which increases susceptibility of HSEC to the apoptosis induced by TRAIL and FasL secreted by T cells.

\section{Transcription Factors in Allergic Inflammation}

Th2 cells play a central role in allergic inflammation. Since GATA-3 is a transcription factor playing a decisive role in the development of the Th2 phenotype, it is a promising target for the treatment of allergic diseases [42]. Garn presented captivating data on GATA-3-specific DNAzyme, a molecule that combined the specificity of antisense molecules with an inherent enzymatic activity. Garn et al. [43] compared the anti-allergic capacity of that DNAzyme with GATA-3-specific antisense-DNA and small interfering RNA using preventive and therapeutic strategies in a mouse model of experimental asthma. The intranasal application of DNAzyme showed the most pronounced effects in eosinophil numbers in the BAL fluid, on local IL-5/IFN- $\gamma$ ratios, in histopathology demonstrating reduced airway goblet cell numbers and reduced tissue inflammation. Airway hyperreactivity to methacholine was also reduced in comparison to the untreated group. Notably, effects were only observed after intranasal application [43].

The theme of $\mathrm{T}_{\text {reg }}$ cells was expanded by Schmidt-Weber who demonstrated transcription factors responsible for the regulation of Foxp3, which is in turn decisive on $\mathrm{T}_{\text {reg }}$ cell lineage commitment [44]. The same group (Mantel et al. [44]) indicated that naive $\mathrm{T}$ cells activated in the presence of TGF- $\beta$ and IL- 4 do not have the potential to upregulate FOXP3. Transgenic mice overexpressing GATA-3 in CD4+ T cells had a decreased number of CD4+CD25+FoxP3+ $\mathrm{T}$ cells. On the other hand, $\mathrm{CD} 4+\mathrm{CDC} 25-\mathrm{T}$ cells from these transgenic mice were unable to express FoxP3. The differentiation of naive $\mathrm{T}$ cells into Th2 cells is dependent mainly on IL-4, which induces GATA-3 and GATA-3-suppressed FOXP3 expression. Thus, cytokines present at the time of priming of naive $\mathrm{T}$ cells play a major role in the lineage commitment decision, not only for Th1 and Th2, but also for $\mathrm{T}_{\text {reg }}$ cells [45].
T-bet, STAT1, STAT4, GATA-3, and STAT6 are known to be responsible for lineage commitment into Th1 and Th2 $\mathrm{T}$ cell subsets, respectively. Nouri-Aria presented data on the contribution of T-bet and STAT6 to the regulation of Th1 and Th2 cytokine profiles at the transcriptional level [46]. The group analyzed cutaneous CD3 and T-bet expression compared to CD3 and STAT6 expression on T cells after intradermal injection of grass pollen allergen, Phleum pratense, and tuberculin (purified protein derivatives) in humans. Computerized double immunofluorescence microscopy results showed that antigen challenge caused an increase in the number of CD3+STAT6+ T cells in skin biopsies from atopics, but not in skin biopsies from non-atopic individuals. In contrast, skin challenge with purified protein derivatives led to a significant increase in CD3+T-bet+ cells in non-atopics and to a lesser extent in atopics. Their results support the role of T-bet and STAT6 in the expression of Th1 and Th2 2 responses in humans, respectively.

In conclusion, we must objectively admit that the meeting was a great success, thanks to the organizers and all of the professionals who actively participated in the activities of the congress of the European Academy of Allergology and Clinical Immunology. We look forward to next years' meeting in Gothenburg. We hope that it will again give an excellent opportunity to come together to discuss new findings and disseminate ideas for a better prevention and treatment of allergic diseases. 


\section{References}

1 Akdis M, Blaser K, Akdis CA: T regulatory cells in allergy: novel concepts in the pathogenesis, prevention, and treatment of allergic diseases. J Allergy Clin Immunol 2005;116: 961-968; quiz 969.

$\checkmark 2$ Sakaguchi S: Regulatory T cells: mediating compromises between host and parasite. Nat Immunol 2003;4:10-11.

-3 Hawrylowicz CM, O'Garra A: Potential role of interleukin-10-secreting regulatory $\mathrm{T}$ cells in allergy and asthma. Nat Rev Immunol 2005;5:271-283.

$\checkmark 4$ Maloy KJ, Powrie F: Regulatory T cells in the control of immune pathology. Nat Immunol 2001;2:816-822.

5 Battaglia M, Stabilini A, Roncarolo MG: Rapamycin selectively expands CD4+CD25+ FoxP3+ regulatory T cells. Blood 2005;105: 4743-4748.

6 Coenen JJ, Koenen HJ, van Rijssen E, Hilbrands LB, Joosten I: Rapamycin, and not cyclosporin A, preserves the highly suppressive CD27+ subset of human CD4+CD25+ regulatory T cells. Blood 2006;107:1018-1023.

7 Akbar AN, Fletcher JM: Memory T cell homeostasis and senescence during aging. Curr Opin Immunol 2005;17:480-485.

$\checkmark 8$ Kapsenberg ML: Dendritic-cell control of pathogen-driven T-cell polarization. Nat Rev Immunol 2003;3:984-993.

$\checkmark 9$ Orlandi A, Grasso F, Corinti S, Marinaro M, Bonura A, Boirivant M, Colombo P, Di Felice G: The recombinant major allergen of Parietaria judaica and its hypoallergenic variant: in vivo evaluation in a murine model of allergic sensitization. Clin Exp Allergy 2004; 34:470-477.

10 Di Felice G, Afferni C, Butteroni C, Capobianco F, Corinti S, Colombo P, Bonura A, Boirivant M, Mastrangeli G: Intranasal administration of probiotic bacteria prevents the development of a Th2 response in a mouse model of allergic sensitisation to the Parietaria judaica major allergen. XXVth Congress of the EAACI, Vienna, 2006, Abstract 29:10.

-11 Harrington LE, Hatton RD, Mangan PR, Turner H, Murphy TL, Murphy KM, Weaver CT: Interleukin 17-producing CD4+ effector $\mathrm{T}$ cells develop via a lineage distinct from the T helper type 1 and 2 lineages. Nat Immunol 2005;6:1123-1132.

-12 Weaver CT, Harrington LE, Mangan PR, Gavrieli M, Murphy KM: Th17: an effector CD4 T cell lineage with regulatory $\mathrm{T}$ cell ties. Immunity 2006;24:677-688.

$\checkmark 13$ Veldhoen M, Hocking RJ, Atkins CJ, Locksley RM, Stockinger B: TGF $\beta$ in the context of an inflammatory cytokine milieu supports de novo differentiation of IL-17-producing T cells. Immunity 2006;24:179-189.
14 Mangan PR, Harrington LE, O'Quinn DB, Helms WS, Bullard DC, Elson CO, Hatton RD, Wahl SM, Schoeb TR, Weaver CT: Transforming growth factor-beta induces development of the $\mathrm{T}(\mathrm{H}) 17$ lineage. Nature 2006;441:231-234.

15 van Beelen A, Zelinkova Z, Taanman-Kueter E, Zaat S, Kapsenberg M, de Jong E: Bacteria induce protective IL-17-producing Th cells by priming of dendritic cells through muramyldipeptide-mediated ligation of NOD2. XXVth Congress of the EAACI, Vienna, 2006, Abstract 1625:444.

16 Bossios A, Malmhall C, Radinger M, Manneras L, Sjostrand M, Lotvall J: Newly produced Tlymphocytes move to the inflammation sites after airway allergen exposure. XXVth Congress of the EAACI, Vienna, 2006, Abstract 1012:283.

17 Hayashi T, Beck L, Rossetto C, Gong X, Takikawa O, Takabayashi K, Broide DH, Carson DA, Raz E: Inhibition of experimental asthma by indoleamine 2,3-dioxygenase. J Clin Invest 2004;114:270-279.

18 Brenk MS, Wilms H, Bieber T, von Bubnoff D: Impaired stimulatory capacity by tryptophan-deprived dendritic cells. XXVth Congress of the EAACI, Vienna, 2006, Oral Abstract 1006:282.

19 Schakel K, von Kietzell M, Hansel A, Ebling A, Schulze L, Haase M, Semmler C, Sarfati M, Barclay AN, Randolph GJ, Meurer M, Rieber EP: Human 6-sulfo LacNAc-expressing dendritic cells are principal producers of early interleukin-12 and are controlled by erythrocytes. Immunity 2006;24:767-777.

20 Zuany-Amorim C, Sawicka E, Manlius C, Le Moine A, Brunet LR, Kemeny DM, Bowen G, Rook G, Walker C: Suppression of airway eosinophilia by killed Mycobacterium vaccaeinduced allergen-specific regulatory T-cells. Nat Med 2002;8:625-629.

21 Peng G, Guo Z, Kiniwa Y, Voo KS, Peng W, Fu T, Wang DY, Li Y, Wang HY, Wang RF: Toll-like receptor 8 -mediated reversal of $\mathrm{CD} 4+$ regulatory $\mathrm{T}$ cell function. Science 2005;309:1380-1384.

22 Fuchs B, Lauenstein H, Krug N, Gunzman C, Braun A: Asthma preventive effect of BBPcysPEG/IFN-gamma treatment in a mouse model induced by grass pollen allergen. XXVth Congress of the EAACI, Vienna, 2006, Abstract 173:57.

23 Sackesen C, Akdis M, Zumkehr J, Alkan S, Blaser K, Gursel I, Akdis CA: Effect of suppressive oligonucleotides on toll-like receptors 3-, 7-, 9-induced B cell activation and antibody production. XXVth Congress of the EAACI, Vienna, 2006, Abstract 34:12.

24 Marth K, Focke M, Valenta R: Evidence for a stable repertoire of allergen-specific IgE antibodies in allergic patients. XXVth Congress of the EAACI, Vienna, 2006, Abstract $22: 8$.
25 Schaub B, Lauener R, von Mutius E: The many faces of the hygiene hypothesis. J Allergy Clin Immunol 2006;117:969-977; quiz 978

26 Ege MJ, Bieli C, Frei R, van Strien RT, Riedler J, Ublagger E, Schram-Bijkerk D, Brunekreef $B$, van Hage M, Scheynius A, Pershagen G, Benz MR, Lauener R, von Mutius E, BraunFahrlander C: Prenatal farm exposure is related to the expression of receptors of the innate immunity and to atopic sensitization in school-age children. J Allergy Clin Immunol 2006;117:817-823.

$>27$ Renz H, Blumer N, Virna S, Sel S, Garn H: The immunological basis of the hygiene hypothesis. Chem Immunol Allergy 2006;91: 30-48.

$>28$ Sampson HA: 9. Food allergy. J Allergy Clin Immunol 2003;111:S540-S547.

29 Ozdemir C, Sel S, Scholl I, Yildimir AO, Bluemer N, Garn H, Ackerman U, Barlan IB, Renz H, Sel S: Mesenteric CD4+ T cells from mice with food-induced intestinal immediate-type hypersensitivity induce airway hyperreactivity. XXVth Congress of the EAACI, Vienna, 2006, Abstract 99:33.

30 Klemm S, Gutermuth J, Hultner L, Sparwasser T, Behrendt H, Peschel C, Mak TW, Jakob T, Ruland J: The Bcl10-Malt1 complex segregates Fc epsilon RI-mediated nuclear factor kappa B activation and cytokine production from mast cell degranulation. J Exp Med 2006;203:337-347.

31 Maurer M, Metz M: The status quo and quo vadis of mast cells. Exp Dermatol 2005;14: 923-929.

32 Mete N, Akdis M, Zumkehr J, Akdis CA: Suppression of basophil activation via histamine receptor 2. XXVth Congress of the EAACI, Vienna, 2006, Abstract 208:69.

>33 Peng T, Hao L, Madri JA, Su X, Elias JA, Stahl GL, Squinto S, Wang Y: Role of C5 in the development of airway inflammation, airway hyperresponsiveness, and ongoing airway response. J Clin Invest 2005;115:1590-1600.

34 Kohl J, Baelder R, Lewkowich IP, Pandey MK, Hawlisch H, Wang L, Best J, Herman NS, Sproles AA, Zwirner J, Whitsett JA, Gerard C, Sfyroera G, Lambris JD, Wills-Karp $\mathrm{M}$ : A regulatory role for the $\mathrm{C} 5 \mathrm{a}$ anaphylatoxin in type 2 immunity in asthma. J Clin Invest 2006;116:783-796.

35 Peng T, Su X, Kumor K, Liu-Chen S, Zhou H, Miano D, Shen Y, Wang Y: Effect of blocking intrapulmonary activation of complement cascade on the development of airway hyperresponsiveness: utility in sight? XXVth Congress of the EAACI, Vienna, 2006, Abstract 122:41 
36 Nassenstein C, Braun A, Erpenbeck VJ, Lommatzsch M, Schmidt S, Krug N, Luttmann W, Renz H, Virchow JC Jr: The neurotrophins nerve growth factor, brain-derived neurotrophic factor, neurotrophin-3, and neurotrophin- 4 are survival and activation factors for eosinophils in patients with allergic bronchial asthma. J Exp Med 2003;198: 455-467.

37 Nassenstein C, Mohring UH, Luttmann W, Virchow JC Jr, Braun A: Differential expression of the neurotrophin receptors p75NTR, TrkA, TrkB and TrkC in human peripheral blood mononuclear cells. Exp Toxicol Pathol 2006;57(suppl 2):55-63.

38 Sundstrom Y, Berg L, Nilsson C, Lilja G, Karre K, Troye-Blomberg M: An altered natural killer cell phenotype in early life increases the risk of allergy development. XXVth Congress of the EAACI, Vienna, 2006, Abstract 261:84.
39 Sonkoly E, Muller A, Lauerma AI, Pivarcsi A, Soto H, Kemeny L, Alenius H, Dieu-Nosjean MC, Meller S, Rieker J, Steinhoff M, Hoffmann TK, Ruzicka T, Zlotnik A, Homey B: IL-31: a new link between T cells and pruritus in atopic skin inflammation. J Allergy Clin Immunol 2006;117:411-417.

40 Akdis CA, Blaser K, Akdis M: Apoptosis in tissue inflammation and allergic disease. Curr Opin Immunol 2004;16:717-723.

41 Basinski T, Holzmann D, Zimmermann M, Radivojevic V, Schmid-Grendelmeier P, Blaser K, Jutel M, Akdis CA: Activation and apoptosis of sinus epithelial cells in chronic rhinosinusitis. XXVth Congress of the EAACI, Vienna, 2006, Abstract 694:199.

42 Nakamura Y, Hoshino M: TH2 cytokines and associated transcription factors as therapeutic targets in asthma. Curr Drug Targets Inflamm Allergy 2005;4:267-270.
43 Garn HS, Wegmann M, Dicke T, Renz H: Treatment of experimental asthma using a GATA-3-specific DNAzyme. XXVth Congress of the EAACI, Vienna, 2006, Abstract 177:58.

44 Mantel PY, Ouaked N, Ruckert B, Karagiannidis C, Welz R, Blaser K, Schmidt-Weber CB: Molecular mechanisms underlying FOXP3 induction in human T cells. J Immunol 2006;176:3593-3602.

45 Mantel P, Kuipers H, Ouaked N, Ruckert B, Karagiannidis C, Lambrecht B, Blaser K, Schmidt-Weber C: GATA-3 as a regulator of peripheral tolerance. XXVth Congress of the EAACI, Vienna, 2006, Abstract 1021:285.

46 Nouri-Aria K, Furukido K, Martins S, Jacobson M, Radulovic S, Banfield G, Durham S: Transcription factors STAT6 and T-bet mediate Th2 and Th1 responses following cutaneous allergen and PPD challenge in man. XXVth Congress of the EAACI, Vienna, 2006, Abstract 1017:284. 